\title{
REDEPOSITED EEMIAN MARINE CLAY IN SOMERO, SOUTH-WESTERN FINLAND
}

\author{
J. J. Donner and R. Gardemeister
}

\begin{abstract}
Donner, J. J. and Gardemeister, R. 1971: Redeposited Eemian marine clay in Somero, south-western Finland. Appendix by Risto Tynni. Bull. Geol. Soc. Finland 43, $73-88$.

Samples from a $33.3 \mathrm{~m}$ deep borehole of early Flandrian clay in Somero, south-western Finland, were studied. The thick clay, although similar in origin to the varved clays in the area, is here without clearly developed varves. Pollen analysis showed that most or all pollen was redeposited Eemian pollen, also representing the Eemian climatic optimum, and the diatoms confirmed the marine origin of the redeposited clay. The Somero clay, together with earlier finds of marine Eemian clay in the south-eastern parts of Fennoscandia, as in Rouhiala, Karelia, prove that southern Finland was more submerged during the climatic optimum of the Eemian interglacial than during the Litorina Sea period of the Flandrian.
\end{abstract}

J. J. Donner, Department of Geology and Palaeontology, University of Helsinki, Finland.

R. Gardemeister, The Geotechnical Laboratory of the State Institute for Technical Research, Otaniemi, Finland.

Risto Tynni, Geological Survey of Finland, Otaniemi, Finland.

In the summer of 1967 the Geotechnical Laboratory of the State Institute for Technical Research, Otaniemi, carried out investigations of the Pleistocene deposits in the Somero area, south-western Finland, under the direction of Gardemeister. In connection with these investigations two borings were made through the thick clay deposits in the area to determine the structure of the sediments. A piston sampler was used, which took $5 \mathrm{~cm}$ cores, $70 \mathrm{~cm}$ or less in length. The first borehole, at an altitude of $92.3 \mathrm{~m}$, was $13.8 \mathrm{~m}$ deep ( $\mathrm{A}$ in Fig. 1 ) and the second, $\mathrm{B}$, at $87.3 \mathrm{~m}$ was $33.3 \mathrm{~m}$ deep. The degree of overconsolidation, the presence of a pollen flora with relatively high percentages of Corylus and trees representing mixed oak forest, at an altitude well above the upper limit of the Litorina Sea, and the presence of some diatoms not found in Late Weichselian or Flandrian clays in Finland, led Gardemeister (1968 a, 1968 b) to conclude that the lower parts of the clays probably are interglacial and the upper parts redeposited and partly mixed interglacial clays. The main emphasis in Gardemeister's work was on the geotechnical properties of the clay and, therefore, the cores from borehole B were used in the present work for a more detailed pollen analysis. Additional samples were taken by 


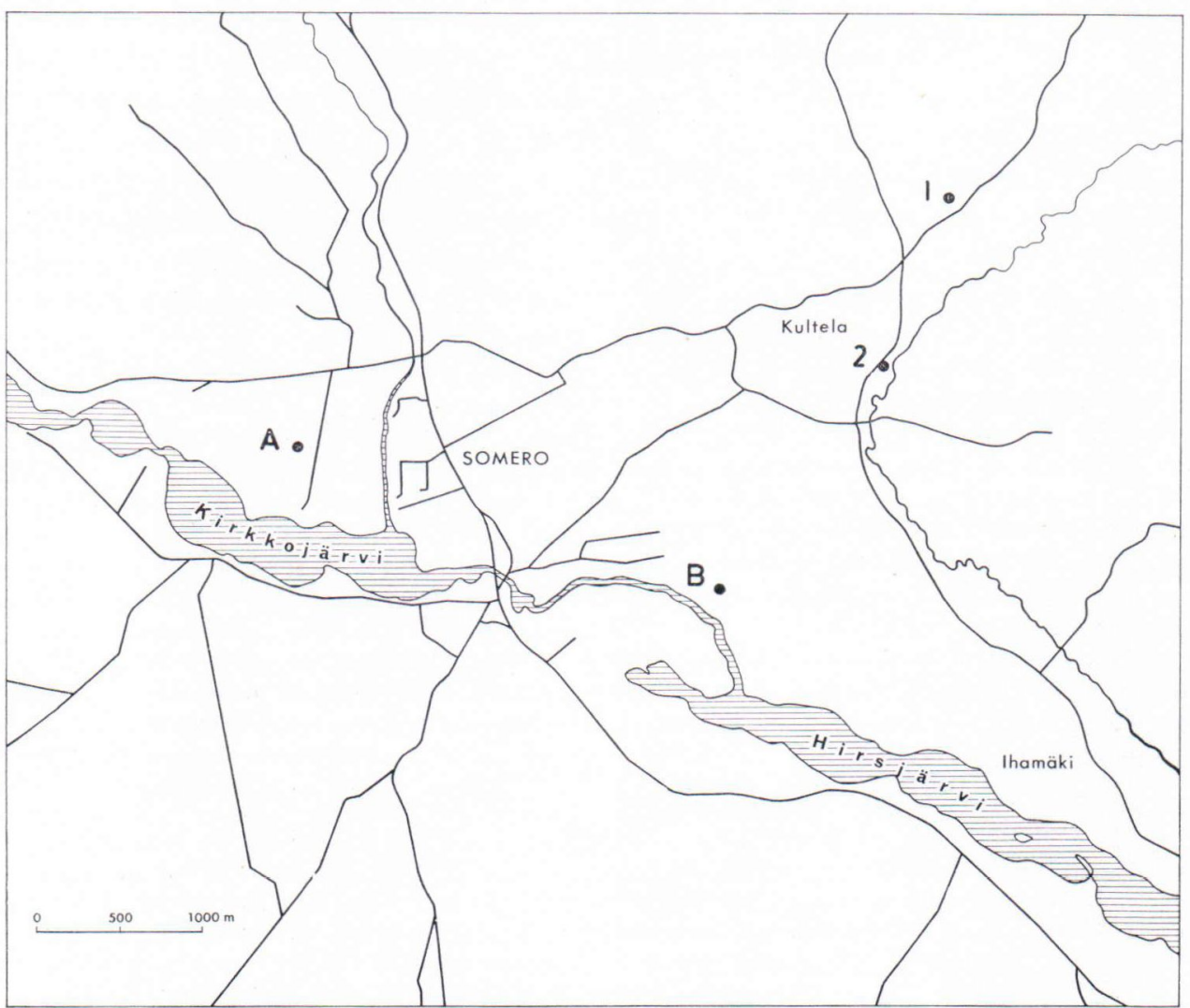

Fig. 1. Map showing sites studied in the Somero area. A and B, boreholes sampled in $1967 ; 1$ and 2, sections studied in 1969.

J. J. D for comparison of the varved clays in the Somero area in the summer of 1969 (Section 1, Fig. 1).

The stratigraphy in borehole B down to $27.5 \mathrm{~m}$ is shown in Fig. 2 with the pollen diagram. Dark grey, lighter grey and pink layers of clay alternate irregularly in the cores, the differences being more distinct in the lower parts. Below $19 \mathrm{~m}$ depth there are deformed parts, between undisturbed layers, in which the pink and dark grey clays are contorted and brecciated, without clear folds or signs of truncation. The varved clays in the clay pits in Somero have similar differences in colour as the clay in borehole B. The $10-15 \mathrm{~cm}$ thick lower varves in the two clay pits studied (1 and 2 in Fig. 1 ) have summer layers of pink clay grading into dark grey winter layers, each varve being clearly separated from the next varve. Thus, already on the basis of the colour changes it can be assumed that the clays in borehole $\mathrm{B}$ represent varved clays but that there were disturbances in the deposition of these clays and that the varves, therefore, were not fully developed. Boreholes A and B with the thick clays lie in a straight valley in a north-west south-easterly direction, probably being a fracture zone of the bedrock. The lakes Kirkkojärvi and Hirsjärvi and the river Someronjoki lie in this valley and a row of short esker ridges is also found near these lakes. The thick clays were formed in the narrow valley immediately outside the retreating ice margin and immediately after 


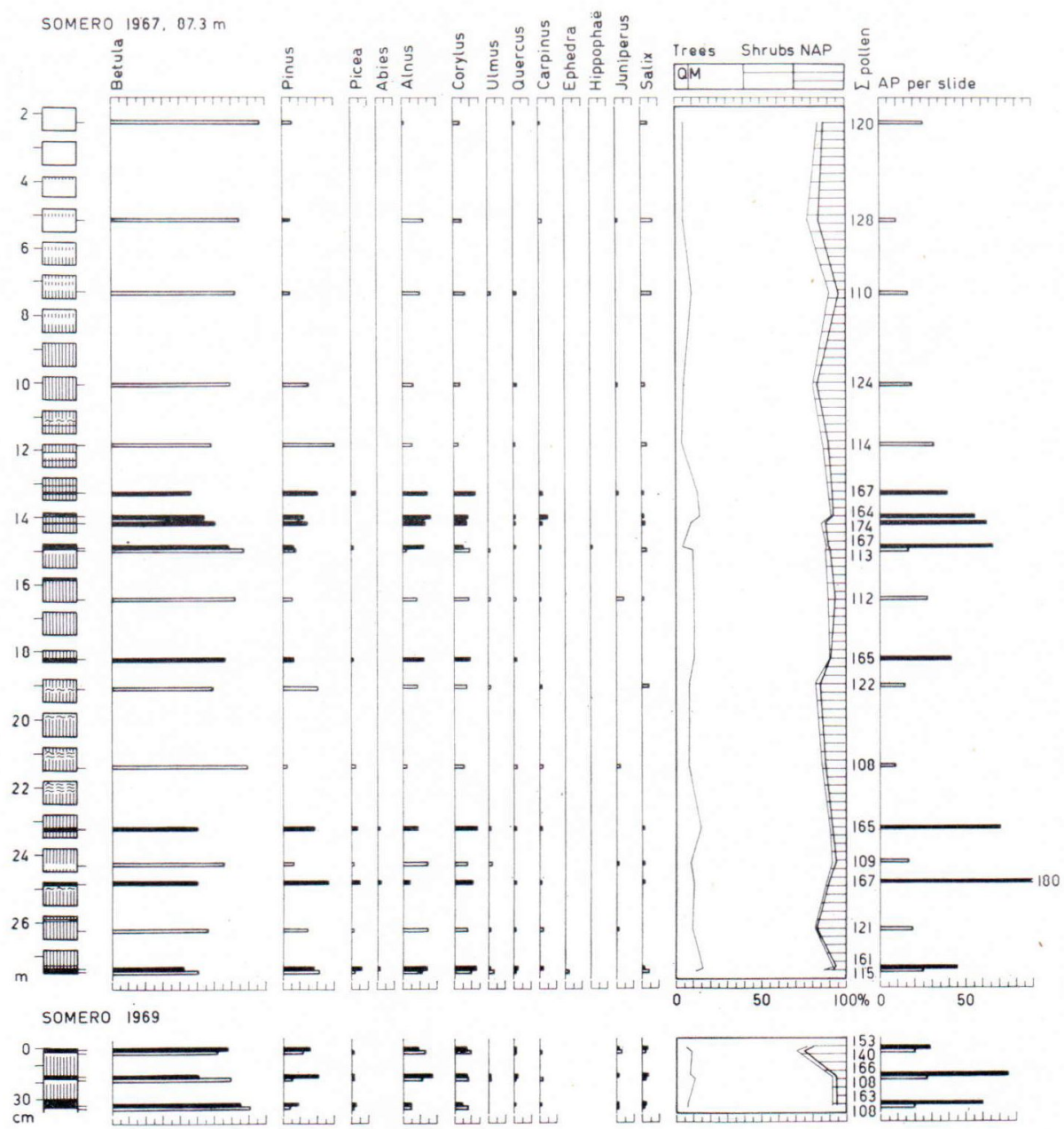

Fig. 2. Pollen diagram for clay from borehole B (1967) and varved clay in section 1 (1969) from Somero (see Fig. 1); pollen of trees and shrubs (anal. J. J. Donner). Stratigraphical symbols: black, pink clay (= summer layer); ruled, light grey clay; white, dark grey clay. Waves show contorted and brecciated layers. Black bars in pollen diagram represent pink clay, white bars light grey or dark grey clay.

the formation of the esker. It is natural that the thickest clays are found near the esker and in the valley, but it is also here that disturbances in the sedimentation of the clays occur. Some may have been caused by turbulence in the water flow near the esker but disturbances may also have been caused by subaqueous sliding, similar to that described by van Straaten (1949) in varved clays in eastern Finland, or by later compaction. Further away from the valley and esker, in slightly more shallow water, the present altitude being between 90 and $100 \mathrm{~m}$, the deposited clays, which must have been formed at the same time as those in the valley, are thinner and clearly varved.

A comparison with the varved clays earlier studied by Sauramo in the Somero area shows that the varved clays in the two pits approxima- 
tely represent the years +200 to +300 in Sauramo's (1923) chronology, which means, if \pm 0 in his chronology is correlated with the latest revised dating of the last drainage of the Baltic Ice Lake in Sweden, i.e. 8213 B.C. (Nilsson 1968, Donner 1969 a), that they were formed in early Flandrian time about $8000-$ 7900 B.C. or $10000-9900$ B.P. At this time the water level was in this area at about 130 $140 \mathrm{~m}$ (Donner 1964, 1969 b), which means

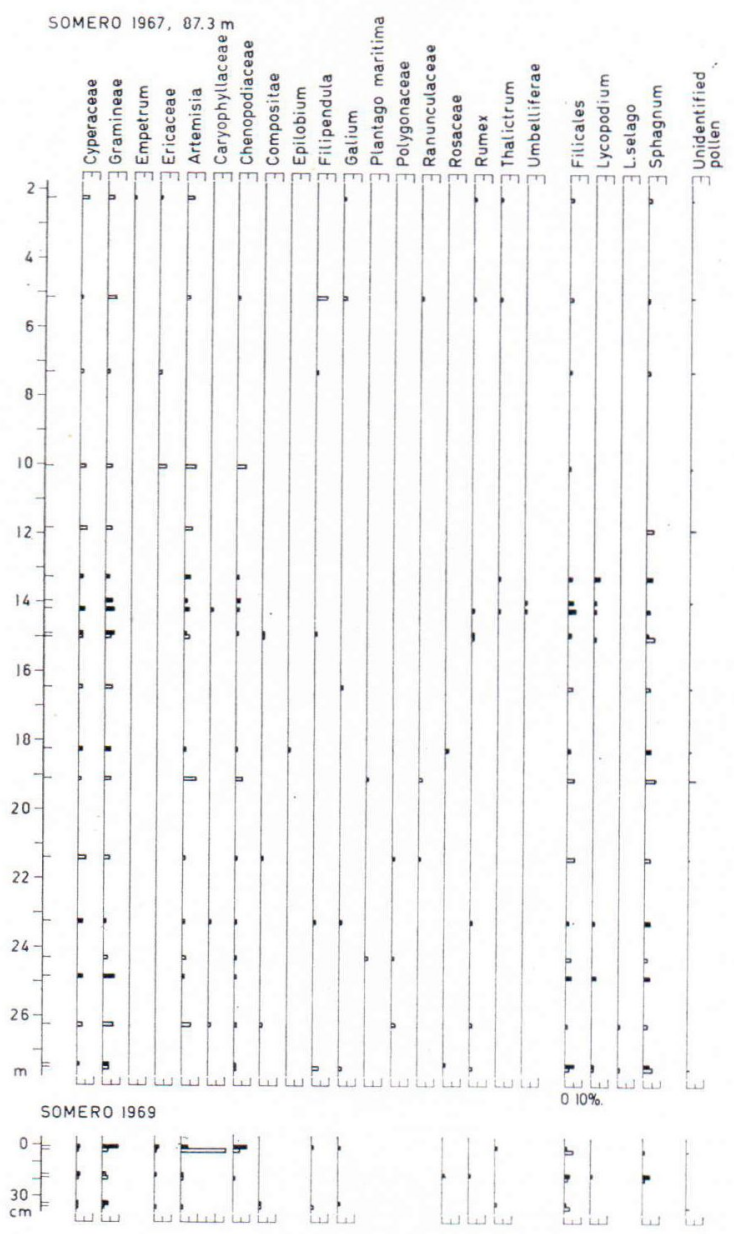

Fig. 3. Pollen diagram for clay from borehole B (1967) and varved clay in section 1 (1969) from Somero; non-tree pollen and spores (anal. J. J. Donner). that the varved clay now at an altitude of 90 $100 \mathrm{~m}$ was deposited in $30-50 \mathrm{~m}$ deep water and the thick clay deposit in borehole $\mathrm{B}$, assuming its age to be the same, in $70-80 \mathrm{~m}$ deep water when the lower parts were formed and the upper parts in $40-50 \mathrm{~m}$ deep water. It can thus be concluded that the about $30 \mathrm{~m}$ thick clays in borehole B, most likely deposited at the same time as the varved clays of the clay pits on higher ground, were deposited in deep water in about one hundred years. The deposition of such thick clays in a short time is, however, restricted to the narrow valley near the esker and therefore exceptional. The rapid deposition is clearly reflected in the pollen diagrams (Figs 2 and 3) in which there are no significant differences between the samples from different depths. In Fig. 2 the percentages are based on the number of pollen of trees and shrubs, all drawn separately. The total diagram including all pollen shows the QM curve, including Corylus, Ulmus, Quercus and Carpinus, trees, shrubs and non-tree pollen (NAP). The pollen sum is given for each sample as well as the number of tree pollen (AP) per slide, the cover glass being $24 \times 32 \mathrm{~mm}$. As about the same amount of material was used for each sample and all were treated with HF the number of tree pollen per slide gives a rough measure of changes and differences in pollen concentration, especially between the pink clay on one hand and the dark grey or light grey clay on the other, as seen in the diagram. As the pink clay has a greater pollen concentration than the grey the number of pollen counted was greater than in the grey clay. Therefore the mean number of taxa found in the pink clay, 13.75 , is slightly higher than the mean for the grey clay, 13.13, the total number of the taxa in the diagram being 31 . There is, however, no significant difference in percentages or pollen composition between the two different clays in the profile, which is dominated by Betula, but in addition to Pinus, has Alnus and Corylus strongly represented. Picea is present in many samples, Abies in a few. Ulmus and Quercus occur irregu- 
larly as well as Carpinus. Of the shrubs Ephedra distacbya was found in one sample, as well as Hippophaë, whereas Juniperus pollen was found in several. The percentages in the NAP diagram (Fig. 3), also giving the spores, were based on 100 tree pollen because the amount of NAP of the total amount of pollen was low, 4-17\%, throughout the diagram, as seen in Fig. 2. No pollen of aquatics was found in any of the samples. A comparison of the pollen composition of the clays of borehole B formed immediately after 10000 B.P. with the pollen composition of $\mathrm{C}^{14}$-dated early Flandrian organic sediments in southern Finland (Salmi 1963, Donner 1963, 1967; Repo and Tynni 1969), which regularly are dominated by Betula but in addition have only Pinus pollen, apart from occasional occurrences of other tree pollen, makes it clear that all or most pollen must be redeposited from older sediments. Further, the percentages of Corylus are higher than in any Flandrian sediments from southern Finland and Carpinus is hardly ever found in Flandrian sediments. The pollen assemblage must therefore be considered to be interglacial, as concluded by Gardemeister (1968 a, 1968 b). The Betula-dominated forests of the Early or Middle Weichselian interstadials demonstrated in northern Finland (Korpela 1969) and central Sweden (Lundqvist 1967) can not have produced the pollen assemblage found in the Somero clays. In Figs 2 and 3 the results of the pollen counts from a few bottom varves from the clay pit in section 1 (Fig. 1) are also given. The pollen composition is similar to that found in borehole B and the difference in pollen concentration between the pink summer layer and grey winter layer is also here clear and confirms the conclusion that the clay material in borehole B comes from the same source as the clay with clearly developed varves and that the different layers in borehole B represent disturbed annual varves.

If all or most of the pollen in the clays studied is redeposited interglacial pollen the clear difference in pollen concentration between the pink summer layers and the grey winter layers has to be explained. The mean value for AP per slide in the Somero 1967 profile in Fig. 2 is for the pink clay 58 and for the grey clay 19, i.e. about a third of that in the summer layer. This
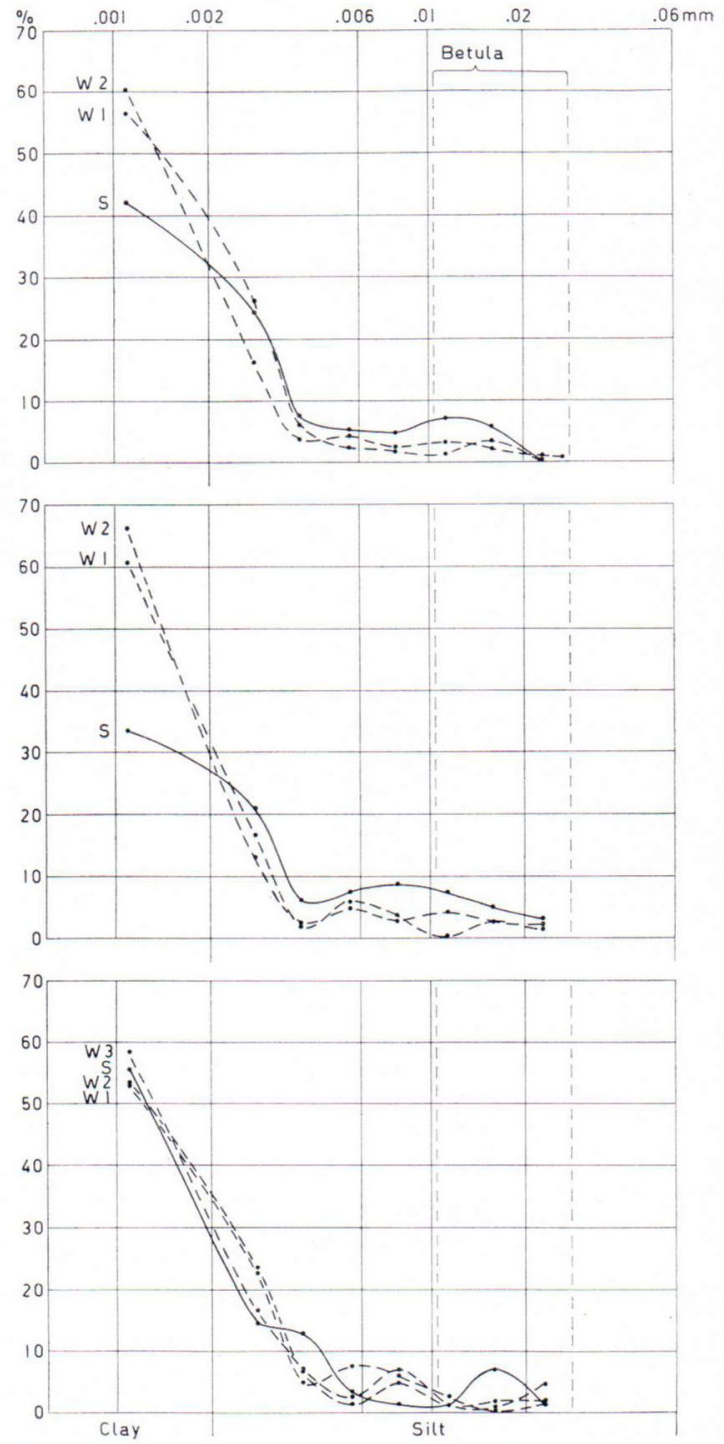

Fig. 4. Percentages of the grain size fractions in three bottom varves from section 1 in Somero (anal. A. E. Kuusisto). S, summer layer; W, winter layer, numbered from base to top. The particle size range, corresponding to the calculated settling velocity of Betula pollen grains, is also shown in the diagram. 
difference would seem natural if the pollen were produced at the same time as the clay was deposited. Then the summer layer, of which the first part represents the first melting in the spring, would be expected to contain more pollen than the winter layer. To elucidate the relationship between the pollen sedimentation and the formation of varves three varves from section 1 (Fig. 1) were more closely studied. The lowermost varve analysed corresponds to the upper of the two varves pollen analytically studied and shown in Fig. 2. The results of the grain size analysis, in which Andreasen's pipette analysis was used, is shown in Fig. 4. A diagram is given for each of the three varves. The percentages for the different fractions of the pink summer layer is given with a full line (S) and for the different parts of the grey to dark grey winter layer with broken lines, numbered from below (W 1, W 2, and in one varve W 3). In the two top varves there is clearly more clay, around $60 \%$, in the winter layer than in the summer layer, whereas in the lowermost varve there is no difference. In all three varves, however, the pink summer layer contains clearly more medium silt $(0.02-0.006 \mathrm{~mm})$ than the winter layer. By experimentally observing the settling velocity of Betula pollen grains in sea water Fries (1951, p. 107-108, see also Jerbo 1965) obtained a value of $0.6-4 \mathrm{~cm}$ per minute, the lower value being caused by the time it took for the settling to begin. Pinus pollen showed a much slower velocity. If Stokes' law, on which the pipette analysis is based, is used the velocity determined by Fries for Betula is equivalent to the settling velocity of clay particles of $0.0108-0.0273 \mathrm{~mm}$ with a specific gravity of 2.6. This particle size range, corresponding to the settling velocity of Betula pollen grains, is also shown in Fig. 4. The comparison shows that the settling velocity of Betula pollen grains, which form the main part of the pollen grains found in the Somero clays, is the same as that for medium silt. Therefore, as the summer layers contain clearly more medium silt than the winter layers it is natural that they also contain more Betula pollen, as well as other pollen. The mean value for AP per slide was in the Somero 1967 (borehole B) profile 58 for the summer layers and 19 for the winter layers, and a similar difference was found in the varves pollen analytically studied (Somero 1969, Fig. 2). It thus seems already from these calculations as if the difference in pollen concentration between the summer and winter layers was only caused by the relatively rapid settling of most of the pollen grains together with most of the medium silt already during the summer. Most of the finer clay particles settled later in the winter and formed the grey layers. The fact that the settling velocities determined by Fries for pollen grains were determined for sea water does not alter these conclusions.

In order to test the validity of the abovementioned conclusions about the sedimentation of pollen in varved clays a varve was artificially produced in the laboratory. $10 \mathrm{~g}$ of air-dried pink clay from the lowermost summer layer of one of the thick bottom varves from section 1 was mixed with $10 \mathrm{~g}$ dark grey clay from the winter layer and dispersed in alchohol by using a mixer. The suspension was poured into a perplex $54 \mathrm{~mm}$ cylinder which was sealed at the bottom with a cork. The depth of the liquid was at the beginning $340 \mathrm{~mm}$. After two weeks the clay material had formed a $5 \mathrm{~mm}$ thick »varve» and the remaining clear liquid, of which in two weeks time about $3 / 4$ had evaporated, was removed. The varve, which had settled on the sealing cork, could be removed with the cork and sampled after it had partly dried. Two samples $2.5 \mathrm{~mm}$ thick were taken from this artificial varve, one from the top "winter» layer and the other from the lower »summer» layer with coarser material. The dry weight was $0.66 \mathrm{~g}$ for each sample. They were treated with HF, after which 5 pollen slides were made from the remaining material of each sample. The total amount of tree pollen found in the two equally big samples was the following: 


\begin{tabular}{|c|c|c|c|}
\hline \multirow[b]{2}{*}{ Abies $\quad \ldots \ldots \ldots \ldots \ldots$} & \multicolumn{2}{|c|}{$\begin{array}{c}\text { Lower } n \text { summer» } \\
\text { layer }\end{array}$} & \multirow{2}{*}{$\begin{array}{l}\text { Upper "winter" } \\
\text { layeI }\end{array}$} \\
\hline & 1 & $(0.5 \%)$ & \\
\hline Picea ............ & 7 & $(3.2 \%)$ & 1 \\
\hline Pinus $\quad \ldots \ldots \ldots \ldots \ldots$ & 45 & $(20.3 \%)$ & 11 \\
\hline Betula .......... & 127 & $(57.2 \%)$ & 20 \\
\hline Alnus .... & 16 & $(7.2 \%)$ & 4 \\
\hline Corylus ... & 21 & $9.5 \%)$ & 3 \\
\hline Quercus $\ldots \ldots \ldots \ldots$ & 3 & $1.4 \%)$ & - \\
\hline \multirow[t]{2}{*}{ Carpinus ............ } & 2 & $0.9 \%)$ & - \\
\hline & 222 & $(100.2 \%)$ & 39 \\
\hline
\end{tabular}

The clear difference in pollen concentration between the coarser wsummer» layer and the finer "winter" layer confirms the conclusion that the greater pollen concentration in the lower summer layers of annual varves is caused by the rapid settling of the pollen grains, the velocity being the same as for medium silt. No significant differences in settling velocity of the different pollen taxa can be demonstrated in the artificial varve, which agrees with the results from the Somero varved clays. Thus, there is in the present investigation no indication of Pinus and Picea pollen grains settling more slowly than pollen grains of other trees. This may be because the pollen grains were already dispersed together with the clay and silt material in the water before deposition, whereas in cases where the pollen grains are produced by the vegetation surrounding the basins in which the sediments are formed the grains float on the water surface for some time before sinking. Differences in the capacity to float may thus cause a slower settling of for instance Pinus pollen grains than Betula pollen grains and in this way the observed unequal distribution of these grains in the sediments.

From the pollen composition in the Somero clays it was concluded that all or most pollen is redeposited from interglacial deposits and that the greater pollen concentration in the summer layers is caused by the settling velocity of the pollen grains. At the time of the formation of the Somero clays outside the retreating ice margin most of south-western Finland was submerged and the pollen production from the vegetation of the emerged islands along the coast at this time must have had a negligible effect if any on the pollen composition of the Somero clays. At most some Betula pollen grains, some pollen of Juniperus and Salix together with some NAP, may be from the early Flandrian vegetation in this area. Pollen grains representing this first plant cover in south-western Finland can not, however, be separated from the others because all pollen taxa may equally well represent an earlier interglacial vegetation. Some pollen grains may be found in the Somero clays because of long distance transport from areas further south. The low pollen concentration in the clay, particularly in the winter layers, makes such occurrences more likely. Therefore, the presence of Ephedra in one sample from a winter layer (Fig. 2) may represent long distance transport, as has been suggested for the other early Flandrian occurrences of Ephedra in southern Finland (Donner 1967), but as it is also found in interglacial deposits, as for instance from $\mathrm{Mga}$ near Lenigrad (Gross 1967), it may equally well be redeposited. Studies in other areas with varved clays formed in surroundings different to those in Finland have led to the conclusion that all or most pollen is redeposited, as first shown by Iversen (1936) in Denmark and later, for instance, by Davis (1961) in Massachusetts. The pollen grains were generally well preserved in the Somero clays, but a comparatively large proportion, $17-37 \%$ of the tree pollen grains in the varves counted from section 1, were deteriorated, some corroded, which has also been noticed in redeposited pollen grains elsewhere (Cushing 1964).

As all or most of the pollen in the Somero clays is interglacial, an Eemian age for at least most of it seems most likely. The diatoms studied by Tynni and discussed in Appendix 1 show that the clay is a redeposited marine sediment, which explains the total absence of any pollen grains of fresh water plants in the samples. In a comparison of the mean tree pollen percentages in the studied Somero clays (Table 1) with the mean percentages of some of the 
TABLE 1

Pollen composition (percentages of total tree pollen) of the Somero clays compared with that of Weichselian till, Eemian clay and some Flandrian deposits

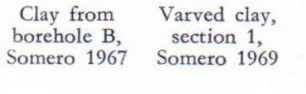

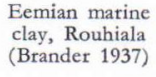
(Brander 1937)
Flandrian peat \& mud (Sauramo) zones IV-IX
Flandrian clay (Mölder 1946, Diagr. 1), zones IV-IX \& VI-VIII

\begin{tabular}{|c|c|c|c|c|c|c|c|}
\hline & & & & & & & \\
\hline Abies $\ldots \ldots \ldots \ldots \ldots \ldots \ldots$ & 0.2 & - & - & - & - & - & - \\
\hline Picea ................. & 1.6 & 1.2 & 6 & - & 6.5 & 1.7 & 1.2 \\
\hline Pinus $\ldots \ldots \ldots \ldots \ldots \ldots$ & 14.1 & 12.3 & 18 & 7 & 32.0 & 56.5 & 46.9 \\
\hline Betula ............. & 62.1 & 67.2 & 61 & 11 & 44.7 & 27.3 & 32.4 \\
\hline Alnus . . . . . . . . . . . & 10.5 & 10.0 & 12 & 52 & 9.9 & 10.7 & 14.2 \\
\hline Corylus .............. & 8.7 & 7.3 & 2.5 & 27 & 4.1 & 0.9 & 1.2 \\
\hline Uimus $\ldots \ldots \ldots \ldots \ldots \ldots$ & 0.5 & 0.3 & 0.4 & 1 & 1.5 & 1.5 & 2.3 \\
\hline Quercus ................ & 1.0 & 1.0 & 0.1 & 1 & 0.2 & 0.2 & 0.5 \\
\hline Tilia $\ldots \ldots \ldots \ldots \ldots \ldots$ & - & - & + & - & 1.1 & 1.0 & 1.5 \\
\hline Carpinus ................ & 1.3 & 0.7 & + & 1 & - & - & - \\
\hline & 100.0 & 100.0 & 100.0 & 100 & 100.0 & 99.7 & 100.2 \\
\hline $\mathrm{QM} \ldots \ldots \ldots \ldots \ldots \ldots$ & 11.5 & 9.2 & 3.0 & 30 & 6.9 & 3.5 & 5.5 \\
\hline Shrubs $\ldots \ldots \ldots \ldots \ldots \ldots$ & 2.5 & 3.2 & 23.8 & & & & \\
\hline NAP $\ldots \ldots \ldots \ldots \ldots \ldots$ & 11 & 14 & & & & & \\
\hline
\end{tabular}

Weichselian tills studied by Heinonen (1957), in for instance Central Ostrobothnia, a striking similarity in the pollen content is found. On the other hand, in comparing the above-mentioned means from Somero and the Ostrobothnian tills with the means calculated for two Flandrian pollen diagrams, one from peats and muds in Pusula, not far from Somero (Sauramo 1958) and the other from Tervajoki in Ostrobothnia (Mölder 1946), some differences can be observed. The Flandrian sediments have, even if the mean is based only on the samples for the climatic optimum, zones VI-VIII, higher percentages for Pinus and lower percentages for Corylus than the Somero samples. Further, the Flandrian diagrams have a mean of $1.0-1.5 \%$ for Tilia whereas the Somero samples and the till samples either lack Tilia altogether or only have occasional occurrences of Tilia pollen grains. Carpinus, on the other hand, is present in the varved clay and the till samples but absent from the Flandrian profiles in Finland. The similarities between the pollen composition of the Somero clays and of known Eemian deposits and tills containing Eemian pollen is obvious. The reason why it is possible to separate an Eemian pollen flora from a Flandrian in the Baltic area is that the Eemian vegetational history, as reflected in the pollen diagrams, differs from the Flandrian. In Eemian diagrams from the Leningrad area (here the Mikulino interglacial), as in the diagrams from Jukki (personal communication by E. S. Maljasova) and Mga * (see Gross 1967), from Estonia, as in a diagram from Röngu near Tartu (Thomson 1941), and from Denmark (Andersen 1965), there is throughout the whole area a marked Carpinus maximum, zone g, after a Corylus maximum, zone $\mathrm{f}$ (for Eemian zoning see Jessen and Milthers 1928, Hansen 1965), unlike Flandrian diagrams. Tilia, on the other hand, is less frequent. It can also be noted that Abies, which occurs in a few of the samples from Somero, is not usually present in Flandrian diagrams. As seen, the pollen composition found in the redeposited clays in Somero indicates that the Eemian vegetational history in southern Finland was similar to that in the areas mentioned above.

When most or all pollen grains and diatoms

* The pollen diagram from Mga is clearly an Eemian diagram (Gross 1967) and the two radiocarbon dates obtained for samples Le-56 and Le-57 giving the ages $36500 \pm 100$ B.P. and $47400 \pm 1400$ (Arslanov 1968) are not conclusive proof for an early or middle Weichselian age for these deposits. 
in the Somero clays are redeposited Eemian fossils it is most likely that the clay and silt, in which these microfossils are found and together with which they settled, is also Eemian, or possibly even older. A partly preglacial or interglacial origin for the Finnish glacial clays and silts has been suggested by particularly Soveri (1956) in discussing their mineralogical composition. If the glacial clays and fine material in the till were foremost rock powder from the Weichselian glaciation they would not contain pollen and diatoms. Thus, the till in the Weichselian ice sheet must have formed from a mixture of new material from the underlying bedrock and of different Eemian sediments, including clays containing pollen and diatoms. It is less likely that clays were separately included in the ice and later redeposited. From this till the clays were washed out and deposited, and the remaining fine fractions in the till has a similar Eemian pollen composition (Heinonen 1957) as the clays unaffected by the pollen rain from the Late Weichselian or early Flandrian vegetation, as are the thick clays at Somero. These are, however, unique because of their pure Eemian pollen composition, whereas in some other clays in southern Finland the redeposited Eemian pollen flora may be obscured by Late Weichselian and particularly by Flandrian pollen to a great degree and its presence, therefore, is difficult to prove and its part of the whole amount of pollen impossible to assess. Further, if only deposits representing the upper or lower part of the Eemian interglacial were redeposited the pollen composition could not in most cases be distinguished from a Flandrian composition. A strong influence of redeposited Eemian pollen, diatoms and clay, however, undoubtedly does occur throughout southern Finland. This is seen in a great number of pollen diagrams of clays, in which the effect of redeposition can clearly be seen when compared with diagrams of contemporary organic sediments without any secondary influence (Sauramo 1949).

The redeposited Eemian clay, containing pollen and diatoms, was, as concluded above, most likely part of the till material in the ice sheet. Hellaakoski (1930) showed that the till material in the Laitila area in south-western Finland is largely local material transported only a few kilometres. Hellaakoski also found that most of the glaciofluvial material in the Laitila esker was transported $5-8 \mathrm{~km}$. Assuming the transport of esker material in Somero to be similar to that in Laitila it is likely that the clay and silt material, deposited at the same time and in the same valley in Somero and also near the ice margin was carried somewhat further by the meltwaters before it settled. It can not, however, originate from an area far away from Somero and it must have come from the direction of the main movement of the ice, from the north-west. The clays at Somero, including the clearly varved clay, occur up to an altitude of about $90-100 \mathrm{~m}$, and the area from which it originated is also at about this altitude. As the clay contains relatively high percentages of both Corylus and Carpinus pollen it must be assumed that the Eemian marine clay, from which the Somero clay was formed, included clays of zones $f$ and $g$, which together in Denmark represent the warmest middle part of the interglacial and correspond to the Eem Sea transgression, which was followed at the end of the interglacial by the transgression represented by the Skaerumhede sequence including a Portlandica arctica zone (see Hansen 1965). The highest shore-line for the Litorina Sea from about $7500-7000$ B.P., corresponding to the warmest part of the Flandrian, is at an altitude of about $55 \mathrm{~m}$ in Somero, thus well below the altitude of $90-100 \mathrm{~m}$ to which the Eem Sea reached here during its warmest part.

A similar relationship of the altitudes is found for the find in Rouhiala, Karelia, of lumps of Eemian marine clay (Brander 1937, 1941). The piece of marine Eemian clay studied by Brander was found in a gravel pit of an esker at an altitude of about $50-65 \mathrm{~m}$ in Rouhiala, now in Soviet Karelia, about $13 \mathrm{~km}$ south-east of Imatra in Finland. The pollen composition of 


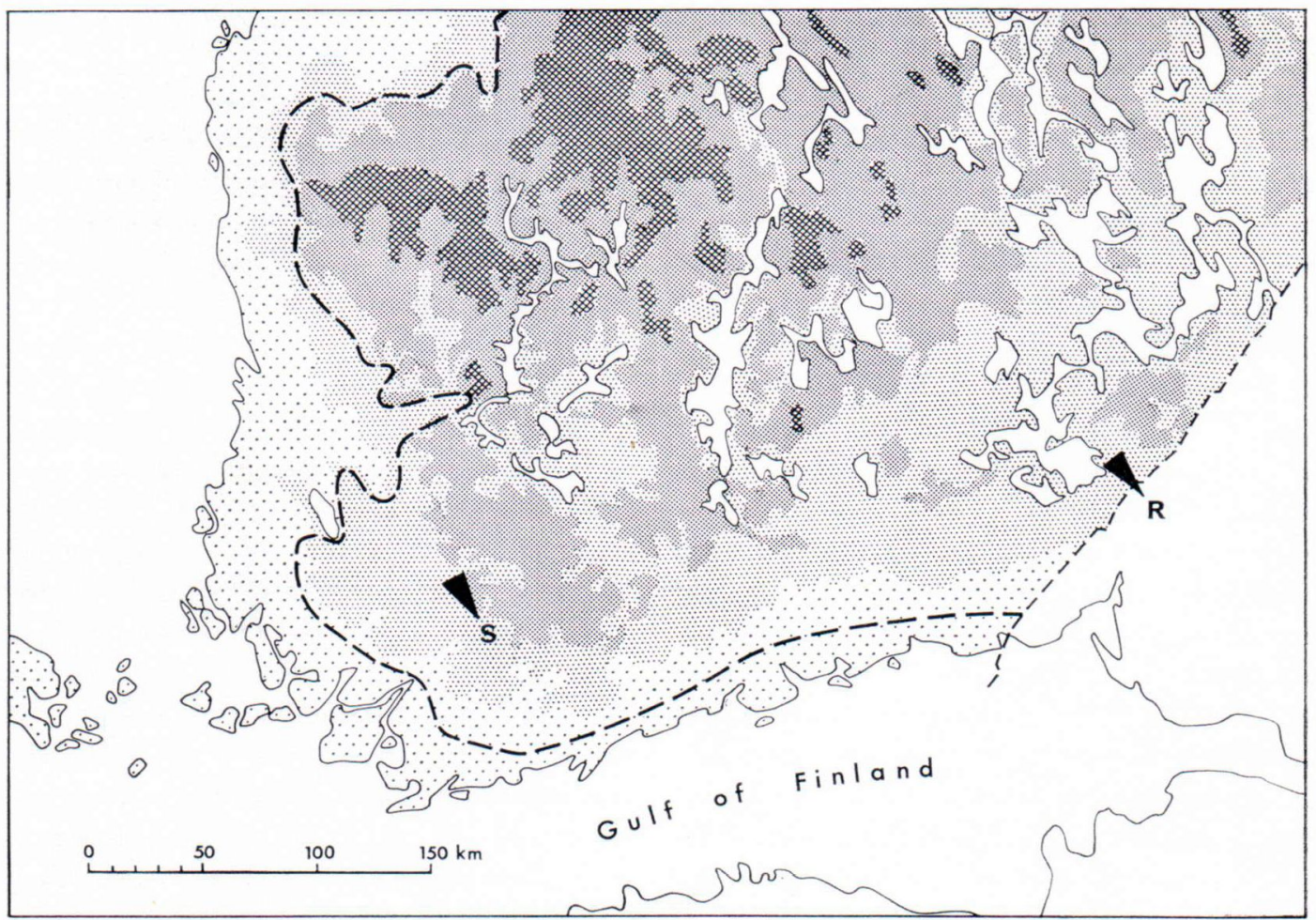

Fig. 5. Map of southern Finland showing the areas from which the redeposited marine Eemian clay found in Somero (S) and Rouhiala (R) most likely was transported. Broken line, highest shore-line for Flandrian Litorina Sea; altitudinal zones from the coast are for $0-50 \mathrm{~m}, 50-100 \mathrm{~m}, 100-150 \mathrm{~m}$ and above $150 \mathrm{~m}$.

the clay with high percentages of Corylus and Alnus (see Table 1) showed that it must at least partly represent the Eemian zone f period. Later clay finds in the same area confirmed this, but one lump had a different pollen composition with high percentages of Picea (Brander 1941) and therefore represents another part of the Eemian. As these pieces of clay were found in glaciofluvial material Brander assumed that they had been transported some distance and he considered it likely that the Eemian marine clay came from the southern part of the present lake Saimaa basin about $20 \mathrm{~km}$ away, a distance of transport in agreement with that assumed above for the Somero clays. The surface of the present lake Saimaa is at an altitude of $76 \mathrm{~m}$ and the altitude for the Litorina Sea would here be, if extrapolated from the isobases at the coast of the
Gulf of Finland (Hyyppä 1937), about $30 \mathrm{~m}$. This difference of $40-50 \mathrm{~m}$ between the Flandrian limit for the Litorina Sea and the altitude to which the transgression of the Eem Sea must have reached is the same as that found in the Somero area. In Fig. 5 the area in which the Eemian marine clays in Somero and Rouhiala were originally assumed to have deposited are shown and also schematically the upper limit for the Flandrian Litorina Sea. The transgression of the Eem Sea during the Eemian zone $f$ and $g$ periods reached at least $40-50 \mathrm{~m}$ above this limit but the total submergence of southern Finland during the last interglacial is not known. The comparatively great submergence, however, must largely have been caused by isostatic movements. A greater Eemian submergence as compared with the Flandrian may be a result of 
the greater load of the more extensive ice sheet in northern Europe during the Saalian glaciation than during the Weichselian glaciation. From several occurrences of marine deposits it has been shown that the Baltic was connected with the White Sea over lakes Ladoga and Onega. This is probably why the waters of the Baltic were comparatively cold, as indicated by the diatoms, at the time of the climatic optimum; a contrast not found in Flandrian sediments formed when the Baltic had no connection with the White Sea. As in Denmark, the transgression of the Eem Sea during the climatic optimum of the Eemian was followed by a later transgression in the White Sea area near the mouth of river Dvina and at Arkhangelsk, representing the transgression of the Portlandia Sea (Zans 1936). The pollen analytical results from Somero and Rouhiala, as well as those from Mga near Leningrad (see Gross 1967), however, show that the earlier transgression of the Eem Sea connected the Baltic with the White Sea. The present investigation, however, does not give any additional information about the relationship between the interglacial transgressions. In Sweden thin layers of partly redeposited drift mud underneath $6 \mathrm{~m}$ of till at Bollnäs, Hälsingland, contain a pollen flora with some Corylus and Alnus pollen in addition to Betula, Pinus and Picea pollen. This shows that they very likely represent a part of an Eemian succession (Andersen 1961, Lungqvist 1967). Brackish water diatoms in some samples show that the Eemian sea-level at one time was higher than the present altitude of $88 \mathrm{~m}$ at which the layers occur. Thus, also in Sweden a high Eemian sea-level position can be traced.

It was concluded that the Somero clays studied are at least partly redeposited marine Eemian clays. The pink colour of their coarser layers, as the summer layers of the varves, is unusual for early Flandrian clays in southern Finland. Analysis of three of the lower varves in section 1 by Mrs. A. E. Kuusisto showed that the content of ferric iron, as that of total iron, is greater in the dark winter layers than in the pink summer layers. The pink colour is undoubtedly caused by $\mathrm{Fe}_{2} \mathrm{O}_{3}$, which, if reduced by $\mathrm{HCl}$, makes the colour of the clay grey. In the winter layers, which contain more organic material than the summer layers, it is the organic matter which gives the layers their dark grey colour, as shown by Arrhenius (1947) for the varved clays in the Uppsala region. Whether the pink colour caused by the ferric iron oxide in any way reflects a higher proportion of redeposited Eemian clay than in the grey varved clays of southern Finland can not be determined on the basis of the present material. The $\mathrm{X}$-ray investigations of the mineralogical composition of the material in the same varves which were chemically analysed give diffraction diagrams similar to those obtained by Soveri (1956) for clays from different parts of Finland. These clays are, on the basis of their mineralogical composition, believed to contain redeposited interglacial and also preglacial clay material (Soveri 1956) and it is possible that the redeposition was more extensive than is generally assumed.

Acknowledgements - The pollen analytical work was done by J. J. D. mainly in the Subdepartment of Quaternary Research, University of Cambridge, during a threemonth visit from October 1969 to January 1970. He is most grateful to Dr. R. G. West for his help during this visit and also to Dr. F. A. Hibbert for his assistance in Cambridge. In addition, he also wants to thank Mrs. A. E. Kuusisto for some of the analyses of the varved clay, as well as Mr. K. Laakso, Dr. M. Saarnisto and Mrs. I. Vuorela for valuable help in the laboratory at the Department of Geology and Palaeontology, University of Helsinki. 


\section{REFERENCES}

Andersen, S. T. (1961) Vegetation and its Environment in Denmark in the Early Weichselian Glacial (Last Glacial). Danm. Geol. Unders., II Raekke, Nr. 75, 175 pp.

- (1965) Interglacialer og interstadialer i Danmarks kvartaer (Zusammenfassung: Interglaziale und Interstadiale im Quartär Dänemarks). Medd. Dansk Geol. Foren. 15 (4), 486-506.

Arrhenius, G. (1947) Den glaciala lerans varvighet. En studie över Uppsala-traktens varviga märgel (Summary: The varvity of the glacial clay. A study of the varved marl in the Uppsala region). Sveriges Geol. Unders. C 486, Årbok 41 (5), 74 pp.

Arslanov, Kh. A. (1968) Khlopin Institute Radiocarbon Dates I. Radiocarbon 10 (2), 446- 447.

Brander, G. (1937) Ein Interglazialfund bei Rouhiala in Südostfinnland. Bull. Comm. géol. Finlande 118, 75 pp.

- (1941) Neue Beiträge zur Kenntnis der interglazialen Bildungen in Finnland. C. R. Soc. géol. Finlande 15; Bull. Comm. géol. Finlande 128, 87-137.

Cushing, E. J. (1964) Redeposited pollen in LateWisconsin pollen spectra from east-central Minnesota. Am. Jour. Sci., 262, 1075-1088.

Davis, M. B. (1961) The problem of rebedded pollen in late-glacial sediments at Taunton, Massachusetts. Am. Jour. Sci., 259, 211-222.

Donner, J. J. (1963) The zoning of the Post-glacial pollen diagrams in Finland and the main changes in the forest composition. Acta Bot. Fennica 65, 40 pp.

- (1964) The Late-glacial and Post-glacial emergence of south-western Finland. Soc. Scient. Fennica, Comm. Physico-Math. 30 (5), 47 pp.

- (1967) The Late-glacial and early Post-glacial pollen stratigraphy of southern and eastern Finland. Comm. Biol. 29 (9), 24 pp.

- (1969 a) Land/sea level changes in southern Finland during the formation of the Salpausselkä endmoraines. Bull. Geol. Soc. Finland 41, 135-150.

- (1969 b) A profile across Fennoscandia of Late Weichselian and Flandrian shore-lines. Comm. Physico-Math. 36 (1), 23 pp.

Fries, M. (1951) Pollenanalytiska vittnesbörd om senkvartär vegetationsutveckling, särskilt skogshistoria, i nordöstra Götaland (Zusammenfassung: Pollenanalytische Zeugnisse der spätquartären Vegetationsentwicklung, hauptsächlich der Waldgeschichte, im nordwestlichen Götaland, Südschweden). Acta Phytogeogr. Suecica 29, 220 pp.

GAR DEMEISTER, R. (1968 a) Interglasiaalista savea Somerolla? (Summary: Interglacial clay at Somero?). Geologi 1968/4, 33-36.
- (1968 b) Etelä-Suomen hienorakeisista sedimenteistä ja niiden ominaisuuksista. Typewritten thesis, Library of dept. of Geol. and Palaeontology, Univ. of Helsinki, $147 \mathrm{pp}$.

Gross, H. (1967) Geochronologie des Letzten Interglazials in nördlichen Europa mit besonderer Berücksichtigung der UdSSR. Schr. Naturw. Ver. Schlesw.Holst. 37, 111-125.

HANSEN, S. (1965) The Quaternary of Denmark (in: Rankama, The Quaternary, Volume 1). John Wiley \& Sons Ltd., London, $1-90$.

Heinonen, L. (1957) Studies on the microfossils in the tills of the north European glaciation. Ann. Acad. Scient. Fennicae A III, 52, 92 pp.

HellaAkoski, A. (1930) On the transportation of materials in the esker of Laitila. Fennia 52 (7), 42 pp.

Нyуррӓ, E. (1937) Post-glacial changes of shore-line in south Finland. Bull. Comm. géol. Finlande 120, $225 \mathrm{pp}$

Iversen, Johs. (1936) Sekundäres Pollen als Fehlerquelle. Danm. Geol. Unders., IV Raekke, Bd. 2, Nr. 15, 24 pp.

Jerbo, A. (1965) Bottniska lersediment, en geologiskgeotcknisk översikt (Summary: Bothnian clay sediments, a geological-geotechnical survey). Geotechnical Dept., Swedish State Railways, Bull. 11, 159 pp.

Jessen, K. and Milthers, V. (1928) Stratigraphical and paleontological studies of interglacial fresh-water deposits in Jutland and northwest Germany. Danm. Geol. Unders., II Raekke, Nr. 48, 379 pp.

Korpela, K. (1969) Die Weichsel-Eiszeit und ihr interstadial in Peräpohjola (nördliches Nordfinnland) im Licht von submoränen Sedimenten. Ann. Acad. Scient. Fennicae A III, 99, 108 pp.

Lundevist, J. (1967) Submoräna sediment i Jämtlands län (Summary: Submorainic sediments in the county of Jämtland, central Sweden). Sveriges Geol. Unders. C 618, 267 pp.

Mölder, K. (1946) Zwei Tonprofile aus Süd-Pohjanmaa. C. R. Soc. géol. Finlande 19; Bull. Comm. géol. Finlande 138, 41-76.

Nrusson, E. (1968) Södra Sveriges senkvartära historia (Summary: The Late-Quaternary history of southern Sweden). Kungl. Svenska Vetenskapsakad. Handl., Fjärde Ser. 12: 1, 117 pp.

Repo, R. and Tynni, R. (1969) Morphologisch-stratigraphische Grundzüge des östlichen Salpausselkä-Gebiets. Bull. Geol. Soc. Finland 41, 203-229.

SALMr, M. (1963) Radiocarbon determinations from the bog profile of Lapaneva, Kihniö, western Finland. C. R. Soc. géol. Finlande 34; Bull. Comm. géol. Finlande 204, 195-205. 
Sauramo, M. (1923) Studies on the Quaternary varve sediments in southern Finland. Fennia 44 (1), 164 pp.

- (1949) Das dritte Scharnier der fennoskandischen Landhebung. Soc. Sci. Fennica, Årsbok-Vuosikirja 27 (4), 26 pp.

- (1958) Die Geschichte der Ostsee. Ann. Acad. Sci. Fennicae A III, 51, 522 pp.

Soveri, U. (1956) The mineralogical composition of argillaceous sediments of Finland. Ann. Acad. Sci. Fennicae A III, 48, 32 pp.

van Straften, L. M. J. U. (1949) Occurrence in Finland of structures due to subaqueous sliding of sediments.
C. R. Soc. géol. Finlande 22; Bull. Comm. géol. Finlande 144, 9-18.

Tномson, P. W. (1941) Die Klima- und Waldentwicklung des von K. Orviku entdeckten Interglazials von Ringen bei Dorpat/Estland. Zeitschr. der Deutschen Geol. Gesellschaft 93 (6), 274-282.

Zans, V. (1936) Das letztinterglaziale Portlandia-Meer des Baltikums. C. R. Soc. géol. Finlande 9; Bull. Comm. géol. Finlande 115, 231-250.

Manuscript received, April 24, 1970.

\section{APPENDIX}

\section{THE DIATOMS IN THE SOMERO CLAY}

by

Risto TyNnI

The diatoms found in the samples from boreholes $A$ and B in Somero were discussed by Gardemeister (1968 a, 1968 b), who concluded that the flora represented an interglacial marine flora, similar to that described from Rouhiala (Brander 1937, 1937 b, 1941) and also from Mga. Further, Brander (1941) also found a similar diatom flora in some tills from western Finland. All abovementioned floras differ clearly from those in Late Weichselian varved clays, which are poor in diatoms and contain mostly fresh-water forms, as the varved clay at Jokela (Mölder 1956). In those cases where Late Weichselian or early Flandrian Baltic sediments are rich in diatoms the diatoms have been explained as having been derived from interstadial or interglacial sediments, as in Ostrobothnia (Mölder 1949, Aario 1966, Ignatius and Leskelä 1970). The interstadial deposits in northern Finland, having a radiocarbon age of about 45000 years, contain only freshwater diatoms (Korpela 1969). Some sediments found underneath till from Finland and the Karelian Isthmus have been dated as interstadial or interglacial (Aurola 1949, Sauramo 1940, Hyyppä 1937 b). In some cases they have contained marine diatoms, usually dominated by Grammatophora oceanica, in other cases they have been extremely poor in diatoms and some sediments have not been investigated in detail. In the present diatom investigation the main question is whether or not there was a connection between the Gulf of Finland and the White Sea.

Many of the diatoms shown in Table 1 are marine forms, which during the Flandrian have not thrived in the coastal areas of Finland. The following diatoms belong to these according to Hustedt (1930): Actinoptychus undulatus, Auliscus caelatus, Biddulpbia rhombus, Dimerogramma minor, Grammatophora arcuata, Stephanopyxis turris and Trachyneis aspera. Actinoptychus undulatus is a littoral form found in all seas. Auliscus caelatus and Stephanopyxis turris occur along all European coasts as well as the littoral forms Biddulphia rbombus and Dimerogramma minor. Biddulpbia rbombus is, according to Brander (1941) particularly found in sediments of the Eemian Portlandia Sea. Of the diatoms from Somero Grammatophora arcuata is at present only found in the coastal arctic and antarctic waters. Tracbyneis aspera grows now for instance on the coasts of France (Peragallo 1908). Synedra crystallina is common in Europe and also in those parts of the Baltic with high salinity, and has been present in the coastal waters of south-western Finland at a time when the waters had a salinity at least as high as during the Flandrian Litorina Sea period.

The above-mentioned species are the same as those described by Brander from Rouhiala. Even if they occur in small numbers the number of species makes their presence significant. Grammatophora ocenica, G. marina and Epithemia turgia + var. westermanni are most common, of which $G$. oceanica and $G$. marina are common marine forms, but are also found at present in the brackish waters of the Gulf of Finland and the Gulf of Bothnia, and which are frequently found also in older Flandrian sediments in that area. Epitbemia turgida + var. westermanni grows 